\title{
The Level of Education of Graduates in Romania in the Context of Globalization
}

\author{
Constantin Marius Profiroiu ${ }^{1}$, Petrică Sorin Angheluțăt ${ }^{1, *}$, Petruț Cristian Vasilache $^{1}$, and \\ Cristina Dima ${ }^{1}$ \\ ${ }^{1}$ Bucharest University of Economic Studies
}

\begin{abstract}
.
Research background: Technological changes are one of the reasons for the resizing of jobs. Demographic change is affecting the labour market, both locally and regionally. Thus, together with technological changes, they lead to changes in the level of education of graduates. The process is accentuated by globalization. There are changes in the labour market that require people with higher skills.

Purpose of the article: For Romania, the analysis of the level of education of graduates at regional level, depending on the county, is presented in this article. In the paper, depending on the level of education, the evolution at county level of the number of graduates is presented. At the same time, the evolution of the total number of graduates for the levels of primary-secondary, vocational, high school, post-high school education, respectively for the level of university education, is analyzed.

Methods: Thus, following the analysis, it is observed that, at national level, the number of graduates decreased. Also, for certain levels of education and only for some counties, the number of graduates has increased.

Findings \& Value added: The radiography performed is important for the regional needs' analysis of the labour market. Thus, following the analysis, it was found that most graduates of tertiary education are from university centers: Bucharest, Cluj, Iași, Timiș. Graduates with a high level of knowledges, skills, and competencies have higher opportunities and abilities to identify and occupy a job.
\end{abstract}

Keywords: graduates; educational field; education levels; Romania

JEL Classification: $I 21 ; I 25 ; F 6$

*Corresponding author: sorin.angheluta@gmail.com 


\section{Introduction}

Technological changes are one of the reasons for the resizing of jobs. The process is accentuated by globalization. There are changes in the labour market that require people with higher skills. In the field of education, globalization has increased student mobility. They have the opportunity to move from one region to another, in order to acquire new knowledge, skills and competences. Thus, education can contribute to the process of globalization. In this way, issues related to education are closely linked to globalization. Increasing the level of education of the population allows the improvement of human capital and contributes to increasing productivity [1].

Companies are also facing demographic changes. Therefore, investments in education and training systems must also take these aspects into account. Thus, the manifestation of the professional and personal success of young graduates is influenced by the way in which the transition from school to work takes place. This can influence the subsequent socioeconomic situation of young graduates. At the same time, the students' subsequent educational path is influenced by the social environment. As educational opportunities increase, an existing family educational environment can lead to further future benefits [2]. Parents 'school experience also influences students' attitudes towards education [3,4]. The graduated educational institution, through the way in which the research and the development of the courses are carried out, influences the decisions that the graduates make regarding their future career and success [5]. Knowing how to manage your own knowledge is a skill that teachers can pass on to future graduates [6, 7]. A level of training and performance of teachers contributes to increasing the quality of the educational act. Thus, their participation in training programs leads to an increase in the level of skills of graduates. The labour market demands that educational institutions, and especially universities, get closer and closer to the professional world. This implies a change in working methods and academic culture, a change that will lead to the acquisition of those skills that are really necessary for the labour market [8-12].

Modern education and training programs meet the requirements of the labour market in terms of a high degree of skills. The exchange of knowledge and ideas between students and faculties is possible through the internationalization of tertiary education [13]. Quality of the educational process has become a goal pursued at all levels. The acquisition by tertiary education graduates of the ability to learn throughout life has increased the importance given to the quality of education at the university level [14]. Participation in mobility between different universities is influenced by the quality of education that students receive. The internationalization of education is increasingly pursued by universities. The European Union has proposed that at least $20 \%$ of all tertiary graduates complete part of their studies abroad, respectively to obtain at least 15 credits or to study at least 3 months in other countries [15].

Obtaining a university degree does not automatically imply employment at a job. The guarantee of employment is no longer given by the graduation of a faculty. Getting a good job is not just based on the university education receive. Training in higher education should also be taken into account as students prepare for a variety of non-academic careers [13]. It is found that, in order to develop appropriate work habits, during the studies, graduates need training and volunteering internships [14, 15]. Increasing knowledge through solicitation and collaboration improves the capacity for conceptual understanding and leads to conscious and thoughtful processes for solving the various problems that arise in the workplace [16]. If the focus shifts to quantity, then a decrease in the quality of the standards used can be achieved [17]. Books/paper are among the most commonly used resources for students to learn, followed by laptops [18]. However, for many graduates, the 
use of learning technology has been favorable to further work in the workplace [19]. A good organization of time and resources in the workplace requires skills acquired during study periods. Self-determination and self-efficacy help students gain that confidence that will lead them to high results [20].

In addition to demographic change and technological developments, globalization has accentuated the dynamism of the labour market. The new skills acquired by graduates are changing the structure of the labour market. The level of education of those entering the labour market for the first time also contributes to this aspect. Thus, employment rates are influenced, but also economic growth in general [21]. Increasing the relevance of the skills acquired by graduates offers them real employment opportunities on the labour market. However, throughout life, it is necessary to participate in training programs, either to update previously acquired skills or to acquire new skills.

There is a process of aging population, but also the movement of the population from rural to urban areas. In this context, in a globalized economy, measures are needed to maintain competitiveness. The knowledge, skills and competences that graduates acquire, as well as their relevance, can ensure an increased employability in the labour market. High-level basic knowledge and skills increase the chances of professional and social fulfillment, but also the chances of personal fulfillment.

\section{Methods}

Through this article, an analysis was made of the level of education of graduates at the regional level, depending on the county. The comparative situation of the level of education of the graduates was performed for the counties of Romania, corresponding to the year 2010 , respectively to the year 2017. Also, the evolution of the total number of graduates is presented, for the period 2010-2017. At the same time, for the counties of Romania, the article reflected the situation of the share of graduates according to the level of education, corresponding to 2017. For the period 2010-2017, is analyses the evolution of the total number of graduates for the levels of primary and lower-secondary, vocational, upper secondary, respectively post-secondary. For the level of university education, the article highlights the evolution of the number of graduates corresponding to the period 2014-2017.

\section{Results and Discussions}

Demographic characteristics, as well as social and economic characteristics, influence the educational needs of pupils and students. Graduates' performance may increase based on a high quality of education received. An increased ability to adapt to change is a consequence of acquiring and possessing appropriate social, civic as well as entrepreneurial skills. Changes in education at the level of members of a society reduce inequities and influence social issues [22].

In Romania, in 2017, according to data published by the Romanian National Institute of Statistics [23], for all levels of education, the total number of graduates was 501802 people. Thus, Figure 1 shows the share of graduates by education levels, for 2017 (\%). It is found that primary and secondary school graduates have the highest share (of 34.39\%), followed by high school graduates $(29.62 \%)$. 


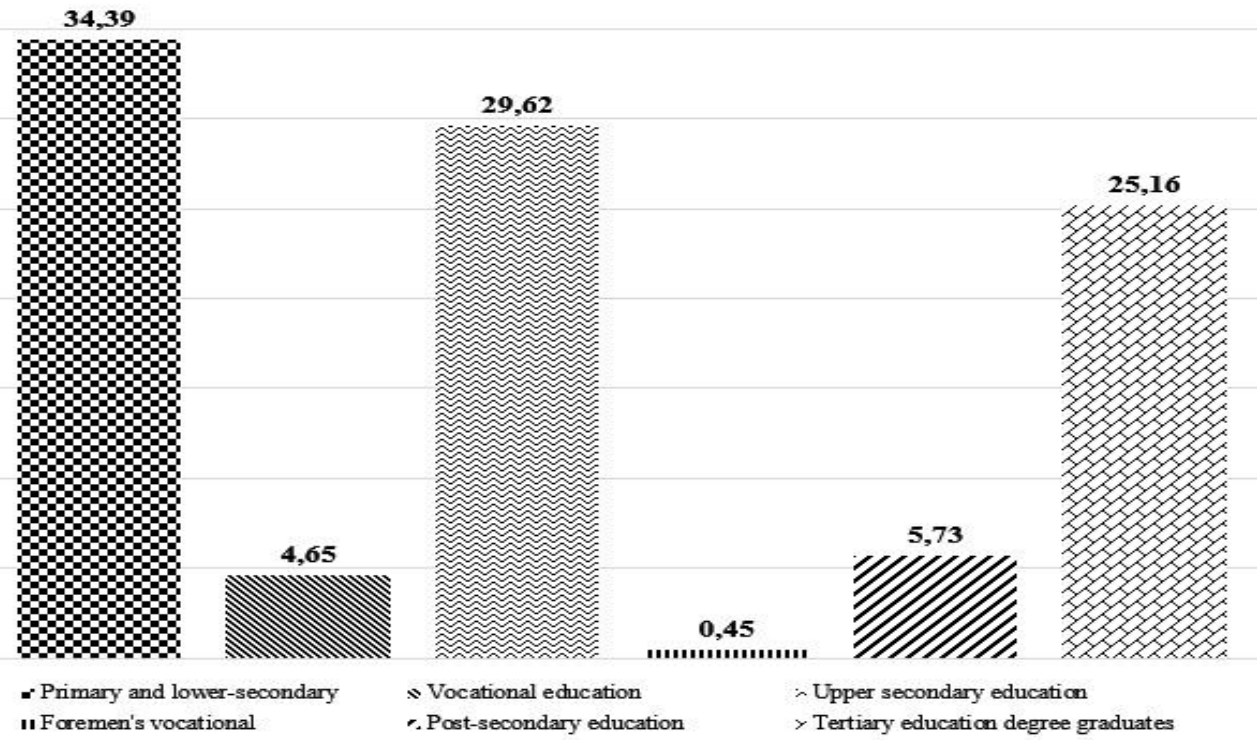

Fig. 1. The share of graduates by education levels, $2017(\%)$.

Figure 2, for the period 2010-2017, shows the evolution of the total number of graduates.

Thus, it is observed that in 2017, compared to 2010, the total number of graduates decreased from 674713 (in 2010) to 501802 (in 2017).

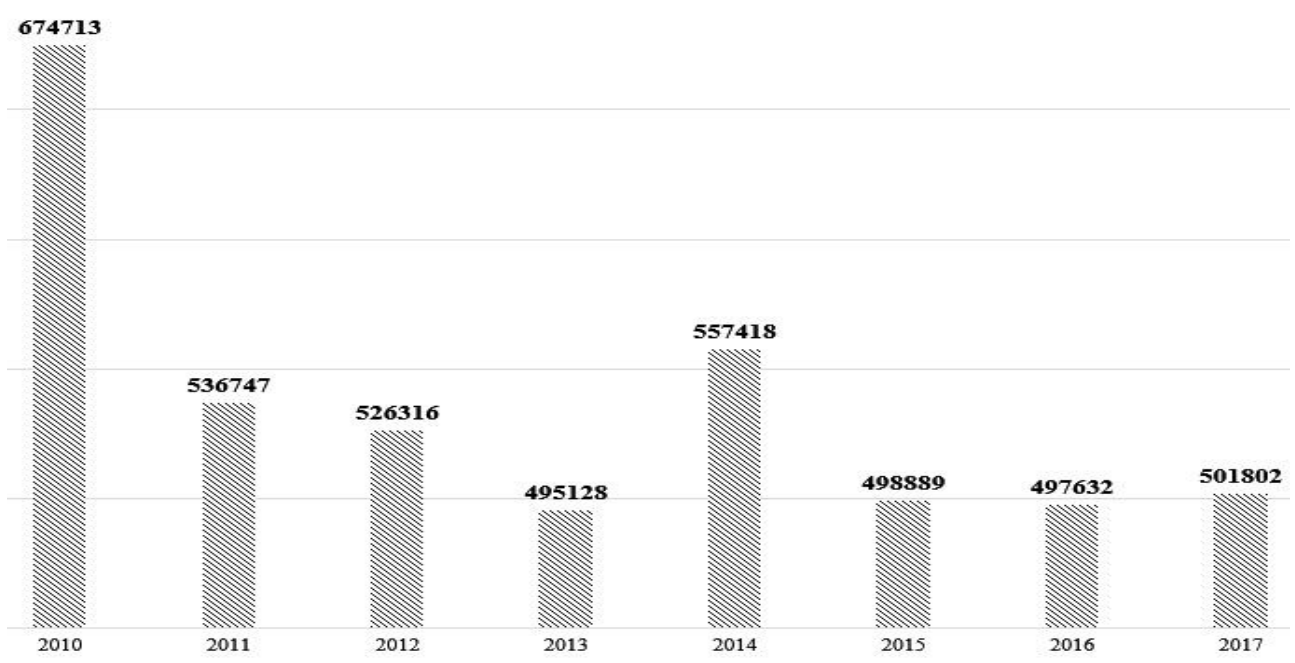

Fig. 2. The evolution of the total number of graduates, 2010-2017.

Table 1 presents the comparative situation of the number of graduates in each county, for 2010 and 2017.

In 2010, apart from Bucharest (with 106591 graduates), the counties with the most graduates were: Iași (30976), Brașov (30489), Constanța (27061), Cluj (26259), Dolj (25317), Timiș (24175), Suceava (21494), Argeș (20562). 
Table 1. The comparative situation of the number of graduates in each county, 2010-2017.

\begin{tabular}{|c|c|c|c|c|c|}
\hline Counties & $\mathbf{2 0 1 0}$ & $\mathbf{2 0 1 7}$ & Counties & $\mathbf{2 0 1 0}$ & $\mathbf{2 0 1 7}$ \\
\hline Alba & 10569 & 8246 & Hunedoara & 13603 & 9282 \\
\hline Arad & 17482 & 10250 & Ialomița & 6445 & 4320 \\
\hline Argeș & 20562 & 15334 & Iași & 30976 & 29221 \\
\hline Bacău & 17112 & 13551 & Ilfov & 5741 & 4425 \\
\hline Bihor & 19681 & 15300 & Maramureș & 14257 & 10737 \\
\hline Bistrița-Năsăud & 8128 & 6444 & Mehedinți & 7984 & 5827 \\
\hline Botoșani & 10597 & 8827 & Mureș & 15404 & 12159 \\
\hline Brașov & 30489 & 13438 & Neamț & 12988 & 9835 \\
\hline Brăila & 7826 & 6083 & Olt & 11475 & 8964 \\
\hline Buzău & 10147 & 8052 & Prahova & 20012 & 15483 \\
\hline Caraș-Severin & 8343 & 5541 & Satu Mare & 9454 & 6674 \\
\hline Călărași & 6574 & 4786 & Sălaj & 5783 & 4423 \\
\hline Cluj & 26259 & 25928 & Sibiu & 15174 & 10751 \\
\hline Constanța & 27061 & 18674 & Suceava & 21494 & 17063 \\
\hline Covasna & 5222 & 3590 & Teleorman & 8226 & 6135 \\
\hline Dâmbovița & 13326 & 9919 & Timiș & 24175 & 20158 \\
\hline Dolj & 25317 & 18197 & Tulcea & 4983 & 3515 \\
\hline Galați & 18120 & 14015 & Vaslui & 11025 & 8379 \\
\hline Giurgiu & 5325 & 3893 & Vâlcea & 11974 & 7735 \\
\hline Gorj & 13460 & 8515 & Vrancea & 7651 & 6219 \\
\hline Harghita & 7698 & 6124 & București & 106591 & 75790 \\
\hline & & & Total & $\mathbf{6 7 4 7 1 3}$ & $\mathbf{5 0 1 8 0 2}$ \\
\hline
\end{tabular}

In 2017, apart from Bucharest (with 75790 graduates), the counties with the most graduates were: Iași (29221), Cluj (25928), Timiș (20158), Dolj (18197), Suceava (17063), Prahova (15483), Argeș (15334), Bihor (15300).

In 2017, compared to 2010, in all counties there were decreases in the number of graduates. The most significant decreases were in Bucharest (-30801) and Brașov (-17051), but also in the counties: Constanța (-8387), Arad (-7232), Dolj (-7120), Argeș (-5228), Gorj (-4945), Prahova (-4529).

In Table 2, for 2017, depending on the level of education, is presented the situation of the share of graduates for each county.

For primary and lower-secondary, the highest values of the share of graduates are in the counties: Bucharest (7.95\%), Iasi (4.56\%), Suceava (4.11\%), Prahova (3.66\%). The lowest values are in: Tulcea (1.03\%), Covasna (1.04\%), Sălaj (1.20\%), Ialomița $(1.21 \%)$, Mehedinți (1.21\%), Caraş Severin (1.35\%), Giurgiu (1.35\%).

In 2017 , compared to 2010 , there were decreases in the number of primary and lowersecondary graduates, in the counties: Suceava (-2617), Iași (-2431), Dolj (-2412), Bacău (2173).

For upper secondary education, the highest weights of graduates are in the counties: Bucharest (10.26\%), Suceava (3.98\%), Iași (3.79\%), Constanța (3.71\%), Argeș $(3.63 \%)$, Prahova (3.60\%). The lowest values: Covasna (0.79\%), Giurgiu (0.86\%), Tulcea $(0.90 \%)$, Ilfov $(0.97 \%)$, Ialomița (1.20\%).

For vocational education, it is observed that high shares of graduates are registered in the counties: Iași $(7.21 \%)$, Suceava $(4.65 \%)$, Bacău $(4.29 \%)$, Prahova $(3.92 \%)$, Bihor $(3.72 \%)$, Cluj $(3.51 \%)$, Dolj $(3.44 \%)$. The lowest values are in: Ilfov $(0.34 \%)$, Giurgiu $(0.50 \%)$, Teleorman $(0.52 \%)$, Mehedinti $(0.78 \%)$, Caras Severin $(0.79 \%)$. 
Table 2. The situation of the share of graduates for each county, depending on the level of education, $2017(\%)$.

\begin{tabular}{|c|c|c|c|c|}
\hline Counties & $\begin{array}{c}\text { Primary and } \\
\text { lower-secondary }\end{array}$ & $\begin{array}{c}\text { Upper secondary } \\
\text { education }\end{array}$ & $\begin{array}{l}\text { Vocational } \\
\text { education }\end{array}$ & $\begin{array}{c}\text { Post-secondary } \\
\text { education }\end{array}$ \\
\hline Alba & 1,72 & 1,98 & 2,20 & 1,49 \\
\hline Arad & 2,05 & 2,21 & 2,11 & 1,67 \\
\hline Argeș & 3,09 & 3,63 & 2,57 & 4,12 \\
\hline Bacău & 3,40 & 2,93 & 4,29 & 2,91 \\
\hline Bihor & 2,95 & 3,15 & 3,72 & 3,10 \\
\hline Bistrița-Năsăud & 1,78 & 1,52 & 2,04 & 1,19 \\
\hline Botoșani & 2,65 & 2,07 & 3,37 & 1,33 \\
\hline Brașov & 2,48 & 2,14 & 3,22 & 2,25 \\
\hline Brăila & 1,59 & 1,54 & 1,80 & 1,21 \\
\hline Buzău & 2,19 & 2,10 & 2,15 & 1,67 \\
\hline Caraș-Severin & 1,35 & 1,51 & 0,79 & 1,50 \\
\hline Călărași & 1,46 & 1,20 & 1,36 & 0,30 \\
\hline Cluj & 2,91 & 3,15 & 3,51 & 3,92 \\
\hline Constanța & 3,46 & 3,71 & 2,46 & 4,32 \\
\hline Covasna & 1,04 & 0,79 & 1,82 & 0,39 \\
\hline Dâmbovița & 2,58 & 2,24 & 1,80 & 1,37 \\
\hline Dolj & 2,77 & 3,21 & 3,44 & 6,63 \\
\hline Galați & 2,74 & 2,75 & 2,74 & 3,41 \\
\hline Giurgiu & 1,35 & 0,86 & 0,50 & 0,55 \\
\hline Gorj & 1,95 & 2,19 & 1,31 & 2,92 \\
\hline Harghita & 1,65 & 1,46 & 2,51 & 0,82 \\
\hline Hunedoara & 1,95 & 2,15 & 1,75 & 4,09 \\
\hline Ialomița & 1,21 & 1,20 & 1,50 & 0,37 \\
\hline Iași & 4,56 & 3,79 & 7,21 & 3,79 \\
\hline Ilfov & 1,61 & 0,97 & 0,34 & 0,26 \\
\hline Maramureș & 2,52 & 2,59 & 3,07 & 1,91 \\
\hline Mehedinți & 1,21 & 1,43 & 0,78 & 2,77 \\
\hline Mureș & 2,75 & 2,37 & 2,81 & 2,68 \\
\hline Neamt & 2,63 & 2,68 & 3,16 & 1,67 \\
\hline Olt & 2,13 & 2,33 & 2,09 & 3,64 \\
\hline Prahova & 3,66 & 3,60 & 3,92 & 3,80 \\
\hline Satu Mare & 1,74 & 1,51 & 2,33 & 1,92 \\
\hline Sălaj & 1,20 & 1,20 & 1,37 & 0,59 \\
\hline Sibiu & 1,98 & 1,78 & 2,28 & 1,41 \\
\hline Suceava & 4,11 & 3,98 & 4,65 & 3,17 \\
\hline Teleorman & 1,56 & 1,87 & 0,52 & 1,16 \\
\hline Timiș & 3,07 & 3,25 & 2,94 & 2,62 \\
\hline Tulcea & 1,03 & 0,90 & 1,05 & 0,50 \\
\hline Vaslui & 2,42 & 2,09 & 3,21 & 1,25 \\
\hline Vâlcea & 1,84 & 2,13 & 1,64 & 2,37 \\
\hline Vrancea & 1,72 & 1,59 & 1,05 & 1,86 \\
\hline București & 7,95 & 10,26 & 2,61 & 11,09 \\
\hline
\end{tabular}

For post-secondary education, the highest values are registered in the counties: Bucharest (11.09\%), Dolj (6.63\%), Constanța (4.32\%), Argeș (4.12\%), Hunedoara (4.09\%), Cluj $(3.92 \%)$, Prahova $(3.80 \%)$, Olt $(3.64 \%)$. The lowest values are in: Ilfov $(0.26 \%)$, Calarasi $(0.30 \%)$, Ialomita $(0.37 \%)$, Covasna $(0.39 \%)$, Tulcea $(0.50 \%)$, Giurgiu $(0.55 \%)$, Sălaj $(0.59 \%)$. 
The following figure shows the evolution of the number of graduates for the levels of primary and lower-secondary, vocational, upper secondary, respectively post-secondary education.

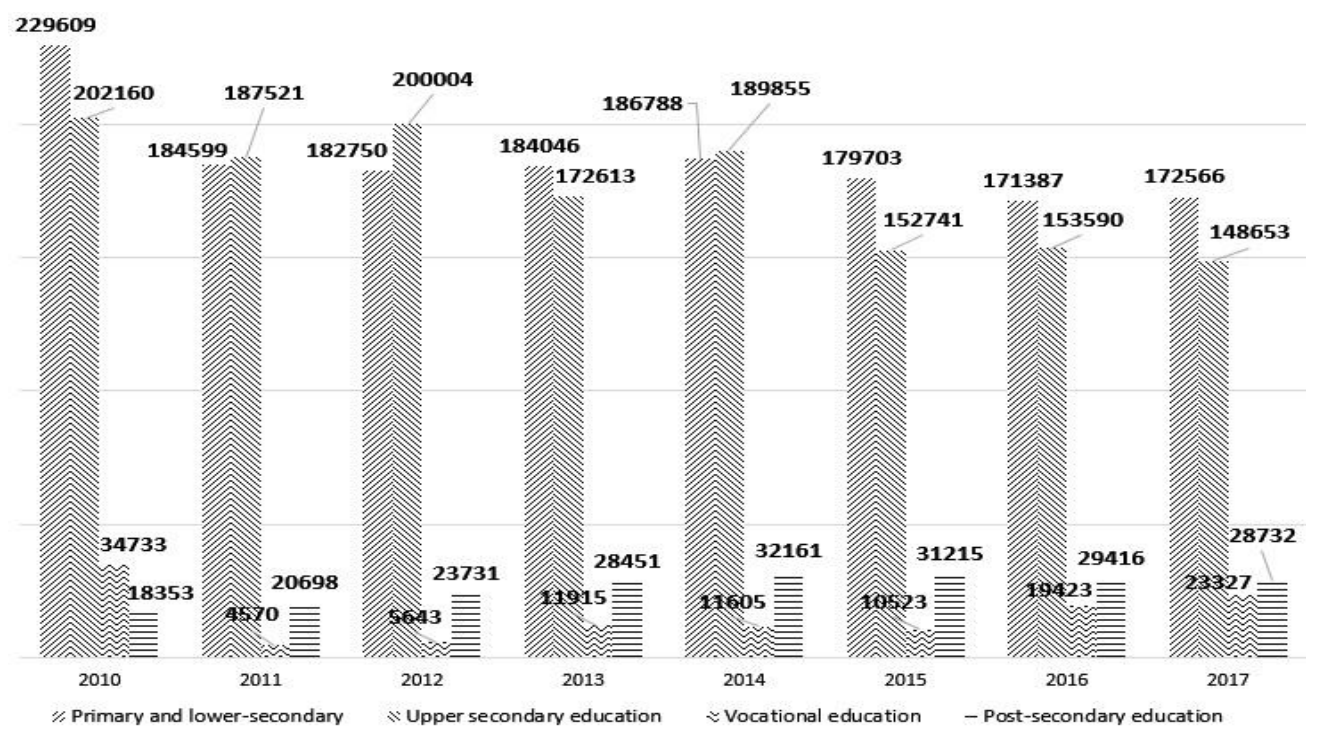

Fig. 3. The evolution of the number of graduates for the levels of primary and lower-secondary, vocational, upper secondary, respectively post-secondary education, 2010-2017.

For the period 2010-2017, the previous figure shows a decrease in the number of graduates for primary and lower-secondary, vocational, respectively upper secondary. It is found that for the level of post-secondary education the number of graduates increased by $56.55 \%$ in 2017 , compared to 2010 . The decrease for the level of primary and lowersecondary education is $24.84 \%$. For the level of upper secondary education, the decrease is $26.47 \%$, and for the level of vocational education the decrease is $32.84 \%$.

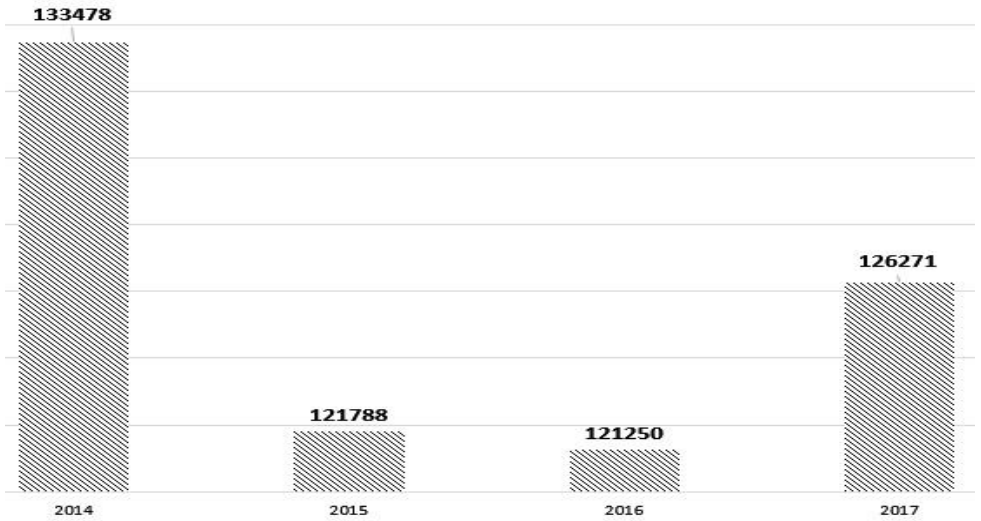

Fig. 4. The evolution of the number of university-level graduates - graduates with a diploma, 20142017.

For the period 2014-2017, the evolution of the number of university-level graduates graduates with a diploma (bachelor's, master's, postgraduate courses, doctorate, and postdoctoral programs) is presented in Figure 4. 
It is observed that, in the period 2014-2016, the number of university graduates decreased from 133478 (in 2014) to 121250 (in 2016). Also, in 2017 their number increased to 126271 .

For 2017, the number of graduates of tertiary education level (Bachelor's, Master's studies, post-graduate classes, $\mathrm{PhD}$ and post-doctoral programs), depending on the county where the universities and faculties are located, and is presented in Table 3.

Table 3. The situation of tertiary education degree graduates, 2017.

\begin{tabular}{|l|c|l|c|}
\hline Counties & $\begin{array}{c}\text { Tertiary education } \\
\text { degree graduates }\end{array}$ & Counties & $\begin{array}{c}\text { Tertiary education } \\
\text { degree graduates }\end{array}$ \\
\hline Alba & 1368 & Harghita & 273 \\
\hline Arad & 2464 & Hunedoara & 947 \\
\hline Argeș & 2700 & Iași & 12878 \\
\hline Bacău & 1475 & Ilfov & 39 \\
\hline Bihor & 3752 & Maramureș & 1250 \\
\hline Bistrița-Năsăud & 287 & Mehedinți & 524 \\
\hline Brașov & 4588 & Mureș & 2408 \\
\hline Brăila & 190 & Neamț & 69 \\
\hline Buzău & 123 & Olt & 165 \\
\hline Caraș-Severin & 320 & Prahova & 1680 \\
\hline Călărași & 63 & Satu Mare & 322 \\
\hline Cluj & 14151 & Sălaj & 72 \\
\hline Constanța & 5145 & Sibiu & 3749 \\
\hline Covasna & 88 & Suceava & 2023 \\
\hline Dâmbovița & 1314 & Teleorman & 203 \\
\hline Dolj & 5775 & Timiș & 8547 \\
\hline Galați & 3455 & Vâlcea & 249 \\
\hline Gorj & 637 & Vrancea & 96 \\
\hline București & 42882 & & \\
\hline & & \multicolumn{2}{|c|}{} \\
\hline
\end{tabular}

From the data presented in the previous table, for 2017, it is found that most graduates in the category of tertiary education degree graduates were registered in the university center of Bucharest (42882). He is followed by the university centers in the counties: Cluj (14151), Iași (12878), Timiș (8547), Dolj (5775), Constanţa (5145), Braşov (4588), Bihor (3752), Sibiu (3749), Galați (3455).

Although it is considered that graduating from a study program provides access to the labour market, however, throughout life it is necessary to continue to update our skills or even to acquire new ones. The need to acquire a new qualification arises as a result of changes in the labour market. These changes are taking place at high speeds and due to digital transformations. Social or economic interactions are manifested without considering space as a problem. The pressure is now on education.

\section{Conclusions}

The new competences, skills and aptitudes that people acquire are the basis for increasing the employment rate. Raising and maintaining the standard of living can be achieved on the basis of an appropriate set of skills and competences. Keeping a balance between the qualifications needs of the company and the competences of employees increases the importance given to education and training programs. Therefore, measures to update professional competences are needed for people who have lost contact with the labour market [24]. 
From the analysis performed at national level, it is observed that in 2017 , compared to 2010 , the total number of graduates decreased. Even if the number of graduates has decreased, Bucharest offers the most graduates. In 2017, after Bucharest, the counties where the total number of graduates was high are: Iași, Cluj, Timiș, Dolj, Suceava, Prahova, Arges,, Bihor. Also, Bucharest, Suceava and Iasi had the most graduates for the primary and lower-secondary level, respectively for the upper secondary education level. Following the analysis, it was found that most graduates of tertiary education are from university centers: Bucharest, Cluj, Iasi, Timis. Thus, the relevance of the analysis is given by the correlation with the regional needs analysis of the labour market.

For graduates who have a high level of knowledge, skills and competencies, the possibilities and abilities to identify and occupy a job are higher. The capacity for professional insertion and social inclusion decreases for graduates who do not have sufficient reading, mathematics and science skills. Young graduates have a higher degree of mobility, due to interventions in the automation of production processes.

The gap between skilled and unskilled staff may increase due to technological innovations and the process of globalization. In order to overcome the changes caused by globalization, the modernization of educational policies can increase the access of all members of a community to quality education and training programs. There is a growing demand for highly skilled labour. One of the solutions to this demand is given by partnerships between educational institutions and companies. At the same time, the higher the level of innovation and creativity, the higher the level of skills. The evolution of education and training systems will provide graduates with the opportunity to acquire more complex skills and competences.

\section{References}

1. Pires de Carvalho Oliveira Silva, C. S., Freire Seoane, M. J., \& Lopez-Bermudez, B. (2019). Un Analisis de la Formacion Terciaria entre los Trabajadores Dependientes e Independientes: El Caso de Portugal (2006-2016). Archivos analiticos de políticas educativas. Revista académica evaluada por pares, independiente, de acceso abierto y multilingüe, 27(46), 2-19.

2. Barclay, K.J. (2018). The birth order paradox: sibling differences in educational attainment. Research in Social Stratification and Mobility, 54, 56-65.

3. Burlacu, S., Enache, A.C., \& Stefan, C. (2013). INcreator-innovative software tool for creation of adaptive education digital content. In The International Scientific Conference eLearning and Software for Education. "Carol I" National Defence University, 2, 238.

4. Barg, K. (2019). Why are middle-class parents more involved in school than workingclass parents? Research in Social Stratification and Mobility, 59, 14-24.

5. Chari, D., \& Potvin, G. (2019). Understanding the importance of graduate admissions criteria according to prospective graduate students. Physical Review Physics Education Research, 15(2), 023101.

6. Burlacu, S. (2011). Characteristics of knowledge-based economy and new technologies in education. Administratie si Management Public, (16), 114-119.

7. de Souza, E. S., Serafim, M. C., \& Santos, L. S. (2019). A contribuição do ensino de ética no desenvolvimento da competência moral de discentes em administração pública. Archivos Analíticos de Políticas Educativas $=$ Education Policy Analysis Archives, 27(1), 66.

8. Gonzalez-Morales, O., Santana-Vega, L.E. (2020). Diseño de un plan de acción para la empleabilidad de los universitarios. Archivos Analíticos de Políticas Educativas, 28(88), 2. 
9. Androniceanu, A., \& Burlacu, S. (2017). Intelligent system for assessment and grading based on docimologic tests. eLearning \& Software for Education, 2, 33-40.

10. Gargallo Lopez, B., Perez-Perez, C., Garcia-Garcia, F.J., Gimenez Beut, J.A., Portillo Poblador, N. (2020). The skill of learning to learn at university. Proposal for a theoretical model. Educacion XX1, 23(1), 19-44.

11. United Nations Educational, Scientific and Cultural Organization (UNESCO). 2018. Global Education Monitoring Report 2019: Migration, Displacement and Education Building Bridges, not Walls. Retrieved from: https://unesdoc.unesco.org/ark:/48223/ pf0000265866

12. Burlacu, S., Rădulescu, C. V., \& BĂLU, O. F. (2018). Forms of Electronic Training. Principles of Educational Games. In Proceedings of the International Conference On Economics and Social Sciences, 1, 36-41.

13. Barthelemy, R.S., McCormick, M., Henderson, C.R., Knaub, A. (2020). Educational supports and career goals of five women in a graduate astronomy program. Physical Review Physics Education Research, 16(1), 010119.

14. Pereira Gonzalez, M., Martis Florez, R., Pascual Diez, J. (2019). Evaluation of career guidance and career education needs in six University Degrees on Education. Bases for the development of the Tutorial Action Plan. Educación XX1, 22(2), 309-334.

15. Burlacu, S., \& Grosu, O. (2009). E-learning through remote laboratories: a new research tool for education assistance. Economy Transdisciplinarity Cognition, (1), 88-90.

16. Mota, A.R., Körhasan, N.D., Miller, K., Mazur, E. (2019). Homework as a metacognitive tool in an undergraduate physics course. Physical Review Physics Education Research, 15(1), 010136.

17. Gale, T., Parker, S. (2017). Retaining students in Australian higher education: cultural capital, field distinction. European Educational Research Journal, 16(1), 80-96.

18. Burlacu, S., \& Jiroveanu, D.C. (2009). IT Governance and Educational Ideal. Administrație și Management Public, 13, 73-82.

19. Andrew, M., Taylorson, J., Langille, D.J., Grange, A., Williams, N. (2018). Student attitudes towards technology and their preferences for learning tools/devices at two universities in the UAE. Journal of Information Technology Education: Research, 17, 309-344.

20. Formanek, M., Buxner, S., Impey, C., Wenger, M. (2019). Relationship between learners' motivation and course engagement in an astronomy massive open online course. Physical Review Physics Education Research, 15(2), 020140.

21. European Commission (2019). Reflection Paper - Towards a Sustainable Europe by 2030. Retrieved from: https://ec.europa.eu/commission/publications/reflection-papertowards-sustainable-europe-2030_en.

22. Organization for Economic Cooperation and Development (2019). Trends Shaping Education 2019, OECD Publishing, Paris. Retrieved from: https://read.oecdilibrary.org/education/trends-shaping-education-2019_trends_edu-2019-en

23. Romanian National Institute of Statistics, (2020). Retrieved from: www.insse.ro

24. European Centre for the Development of Vocational Training (Cedefop) (2018). From long-term unemployment to a matching job: the role of vocational training in sustainable return to work. Luxembourg: Publications Office. Retrieved from: https://www.cedefop.europa.eu/files/3076_en.pdf 